\title{
Immunosuppressive therapy with rituximab in common variable immunodeficiency
}

\author{
Antonio Pecoraro ${ }^{1}$, Ludovica Crescenzi ${ }^{1}$, Maria Rosaria Galdiero' ${ }^{1}$, Giancarlo Marone ${ }^{2,3}$, Felice Rivellese ${ }^{1,4}$, \\ Francesca Wanda Rossi ${ }^{1}$, Amato de Paulis ${ }^{1}$, Arturo Genovese ${ }^{1}$ and Giuseppe Spadaro ${ }^{1 *}$ (D)
}

\begin{abstract}
Common variable immunodeficiency (CVID) is the most frequent symptomatic primary antibody deficiency in adulthood and is characterized by the marked reduction of IgG and IgA serum levels. Thanks to the successful use of polyvalent immunoglobulin replacement therapy to treat and prevent recurrent infections, non-infectious complications, including autoimmunity, polyclonal lymphoproliferation and malignancies, have progressively become the major cause of morbidity and mortality in CVID patients. The management of these complications is particularly challenging, often requiring multiple lines of immunosuppressive treatments. Over the last 5-10 years, the anti-CD20 monoclonal antibody (i.e., rituximab) has been increasingly used for the treatment of both autoimmune and non-malignant lymphoproliferative manifestations associated with CVID. This review illustrates the evidence on the use of rituximab in CVID. For this purpose, first we discuss the mechanisms proposed for the rituximab mediated B-cell depletion; then, we analyze the literature data regarding the CVID-related complications for which rituximab has been used, focusing on autoimmune cytopenias, granulomatous lymphocytic interstitial lung disease (GLILD) and non-malignant lymphoproliferative syndromes. The cumulative data suggest that in the vast majority of the studies, rituximab has proven to be an effective and relatively safe therapeutic option. However, there are currently no data on the long-term efficacy and side effects of rituximab and other second-line therapeutic options. Further randomized controlled trials are needed to optimize the management strategies of non-infectious complications of CVID.
\end{abstract}

Keywords: Common variable immunodeficiency, Antibody deficiency, Autoimmune cytopenias, Granulomatous lymphocytic interstitial lung disease, Rituximab, Anti-CD20

\section{Introduction}

Rituximab (RTX) is a monoclonal antibody (IgG1k) that specifically targets the transmembrane protein $\mathrm{CD} 20$ expressed on pre-B and mature B lymphocytes [1-3]. Binding of RTX to its receptor results in significant depletion of B-cells in lymphoid tissues and peripheral blood by different mechanisms, including apoptosis, complement-dependent cytotoxicity, and antibody-dependent cytotoxicity [4-6]. Since hematopoietic stem cells do not express CD20, one course of treatment with rituximab is

\footnotetext{
*Correspondence: spadaro@unina.it

${ }^{1}$ Department of Translational Medical Sciences and Center for Basic and Clinical Immunology Research (CISI), World Allergy Organization (WAO) Center of Excellence, University of Naples Federico II, Via S. Pansini 5, 80131 Naples, Italy

Full list of author information is available at the end of the article
}

followed by B-cell repopulation of the peripheral blood starting usually within 6 to 9 months [7]. However, a subset of RTX-treated subjects develop prolonged B-cell deficiency and severe hypogammaglobulinemia requiring long-life immunoglobulin replacement [8-10].

RTX was first approved by the FDA in 1997 and by the EMA in 1998 for the treatment of relapsed or refractory, CD20-positive, B-cell, low-grade or follicular non-Hodgkin's lymphoma [11]. In the following two decades, the use of RTX has progressively expanded to include, also with off-label indications, an increasing number of autoimmune diseases [12-15] (i.e., rheumatoid arthritis, antineutrophil cytoplasmic-associated vasculitis, systemic sclerosis, immune thrombocytopenia, etc.) and the EBVrelated lymphoproliferative syndromes associated with bone marrow transplantation $[16,17]$.

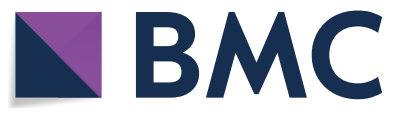

(c) The Author(s) 2019. This article is distributed under the terms of the Creative Commons Attribution 4.0 International License (http://creativecommons.org/licenses/by/4.0/), which permits unrestricted use, distribution, and reproduction in any medium, provided you give appropriate credit to the original author(s) and the source, provide a link to the Creative Commons license, and indicate if changes were made. The Creative Commons Public Domain Dedication waiver (http://creativecommons.org/ publicdomain/zero/1.0/) applies to the data made available in this article, unless otherwise stated. 
Several studies reported the successful use of rituximab for the treatment of autoimmune and lymphoproliferative manifestations associated with primary immunodeficiencies, and in particular with common variable immunodeficiency (CVID) [18-20]. CVID is the most frequent severe antibody deficiency in adulthood and is characterized by the reduction of serum immunoglobulin levels (namely IgG and IgA) and the impairment of antibody production in response to pathogens and vaccines [21, 22]. This may be due either to an intrinsic defect of B-cell development or to a disrupted cross-talk between $B$ and $\mathrm{T}$ cells $[23,24]$. Beyond the impairment of B-cell functions, a number of other immune alterations have been described in CVID patients. Together, these contribute to the establishment of a complex immune dysregulation including naive $\mathrm{T}$ or NK deficiency, expansion of specific B-cell-subpopulations (i.e., CD21low and transitional B-cells), monocyte/macrophage activation, Th1 imbalance of T-helper follicular cells (TFH) associated with a IFN- $\gamma$ driven inflammation and neutrophil-mediated T-cell suppression [25-35]. According to the heterogeneity of the immunological alterations, CVID patients presents a wide spectrum of clinical manifestations including infections, inflammatory and autoimmune diseases, and malignancies (cancer and lymphoma) [36-41]. The heterogeneity of the clinical picture makes CVID diagnosis challenging, thus contributing to the establishment of a significant diagnostic delay that affects both the longterm outcome and the quality of life of CVID patients [42-44]. Therefore, different population-based screening approaches have been recently introduced in the clinical practice to shorten diagnostic delay and improve long-term outcome $[45,46]$. The mainstay of treatment of CVID is immunoglobulin replacement therapy (IgRT). Although immunoglobulin therapy is also used at higher dosage in a wide range of autoimmune and inflammatory conditions for its immunomodulatory effects [47], the main indication of this treatment is the lifelong replacement therapy of antibody deficiency to prevent and treat recurrent infections [48]. New immunoglobulin purification and stabilization methods have been developed thus allowing the administration of higher volumes and higher concentrations of immunoglobulins via both the intravenous and the subcutaneous route [49-55].

Thanks to the successful use of IgRT to treat bacterial infections, autoimmune diseases and malignancies have progressively become the major cause of morbidity and mortality in CVID patients [56-58]. CVID-related autoimmune and lymphoproliferative complications are poorly understood from the pathogenetic point of view and therefore difficult to manage [59]. Interestingly, in a large USA cohort the risk of death was 11 times higher for CVID patients with one or more non-infectious complication than for subjects who had infections only [56]. As consequence, a number of immunosuppressive protocols, which had been traditionally considered contraindicated in immunodeficiency patients over the last decades, have been increasingly used to treat autoimmune diseases and non-malignant lymphoproliferative manifestations associated with CVID [60, 61].

With the increasing evidence of effectiveness in several autoimmune diseases, also RTX has been progressively included in the therapeutic strategies for the non-infectious complications of CVID [19, 62-64]. Although the use of a B-cell depleting monoclonal antibody in a humoral immune deficiency may appear paradoxical, the heterogeneous pathogenesis of CVID, characterized by a complex immune dysregulation beyond the simple impairment of antibody production, could explain the potential efficacy of rituximab in CVID. Although no large randomized controlled trials have been conducted, several case reports, small series and cohort studies investigated the outcomes of RTX in CVID in last 15 years.

This review summarizes the evidence available on the use of rituximab in CVID. For this purpose, first we will discuss the mechanisms of action of RTX, focusing on the effects on the various immune cells; then, we will analyze the data available for the CVID-related complications for whom RTX has been used, namely autoimmune cytopenias, granulomatous lymphocytic interstitial lung disease (GLILD) and non-malignant lymphoproliferation.

\section{Mechanisms of action of rituximab}

Multiple mechanisms have been proposed to explain the efficacy of RTX in autoimmune diseases and nonmalignant lymphoproliferation. These effector mechanisms may act individually or collectively and are only in part ascribable to B-cell depletion. RTX depletes B cells primarily through three different mechanisms: antibody-dependent cell-mediated cytotoxicity (ADCC), complement-mediated cytotoxicity (CMC) and induction of apoptosis (Fig. 1) [65]. Among these, ADCC and CMC seem to be the most accountable for the B-cell depleting effect of RTX in vivo [66].

RTX is an IgG1 monoclonal antibody, which can activate the complement cascade, leading to 3 remarkable effects: (a) the generation of anaphylotoxins (e.g. C5a, C3a) that amplify the recruitment of effector cells; (b) the formation of a membrane attack complex (MAC) that results in the direct cell lysis; and (c) the liberation of cell cleavage fragments that act as opsonins [67, 68]. However, the differential depleting-effect of RTX to B-cells may depend on individual factors, as the 
expression level of the complement regulatory proteins CD46, CD55 and CD59 [69].

The relevance of ADCC for the in vivo response to RTX has been confirmed by the genetic analysis of Fc receptor polymorphisms in populations of treated patients, where FcyRIIIA-158 polymorphisms were shown to increase RTX-induced ADCC and improve clinical outcome [70]. This finding supports the hypothesis that the ADCC is the most important effect exerted by RTX [71, 72]. Consistent with this evidence, RTX was demonstrated to cause polarization of CD20, intercellular adhesion molecule 1 (ICAM-1), myosin, and the microtubule organizing center (MTOC), thus inducing the preferential cell-killing by effector NK cells [73]. However, several other immune cells, including polymorphonuclear cells and macrophages, express activating Fcy receptors. Similar to ADCC, opsonized cells activate Fc $\gamma$ Rs on the phagocyte surface, resulting in an antibody-dependent cell-mediated phagocytosis (ADCP). Also, phagocytes may play an important role in the clearance of apoptotic B cells after RTX treatment [74].

B-cell depletion in peripheral blood after RTX treatment is higher than 99\% [75]. However, this could not reflect the depletive effect in lymphoid tissues, where there can be considerable variations between individuals. A study evaluated the splenic immune responses in patients with immune thrombocytopenia (ITP) to address the immunomodulatory effects of RTX. The authors found marked follicular atrophy and a significant reduction in the number of splenic B lymphocytes in ITP patients treated with RTX. On the contrary, the number of plasma cells was increased in splenic samples from ITP patients who did not improve after RTX treatment [76]. The latter findings support the concept that the long-lived plasma cells, which are not affected by RTX, can sustain pathogenic antibody production for a variable time after RTX, thus being responsible for the poor or delayed clinical response. Of note, in the same individual the depletion's grade tends to be similar in different tissues, suggesting that the extent of B-cell depletion achieved may be influenced by individual factors [77]. Among these, the antigen modulation, which refers to the CD20 endocytosis after binding the antibody, may play an important role, through the reduction of the recruitment of Fc $\gamma$ receptors on effector immune cells [78].

Another cause of incomplete B-cell depletion is the induction of anti-RTX antibody response, which may influence drug action and clearance rates. This phenomenon has been described in patients with autoimmune diseases who received a RTX-retreatment. However, most large studies found no association between the presence of anti-RTX antibodies and clinical outcome [79, 80].
Even though the major part of RTX-immunomodulatory effects are accountable to B-cell depletion, evidence has proved that RTX also may target both helper and cytotoxic T-cells. The effect of RTX on T-cell compartment mainly consists in both the increase of $\mathrm{T}$ regulatory cells and the normalization of Th1/Th2 ratio, which is frequently increased in some autoimmune disorders as ITP. In a study in ITP patients, the major T-cell abnormalities observed were the increase of Th $1 /$ Th 2 ratio, the over-expression of Fas ligand on Th1 and Th2 cells, the over-expression of Bcl-2 mRNA and the expansion of oligoclonal T cells in ITP patients compared to controls [14]. These abnormalities were reverted in RTX-responders after 3 and 6 months of treatment, whereas they remained unchanged in non-responders. Consistently with this findings, a significant increase in the Th1/Treg ratio was detected in splenic samples from ITP patients who failed RTX therapy compared with controls and to ITP patients not treated with RTX [76]. From a theoretical point of view, these results support the use of RTX in autoimmune and lymphoproliferative complications of CVID. Indeed, various studies have recently demonstrated a skewed memory CD4+ T-cell differentiation toward a CXCR3+CCR6- TH1 phenotype both in blood and lymph nodes in patients with CVID and immune dysregulation $[28,29]$.

\section{Autoimmune cytopenias}

Cytopenias, including immune thrombocytopenia (ITP), autoimmune hemolytic anemia (AIHA) and autoimmune neutropenia (AN), are the most common hematological autoimmune disorders in CVID [81]. Autoimmune cytopenias (AC) may be the first evidence of immune dysregulation, preceding the occurrence of recurrent infections and even of hypogammaglobulinemia [82]. In the last report from the European CVID Registry by the European Society for Immunodeficiencies (ESID), AC were found to be correlated with enteropathy, granulomatous disease, splenomegaly and splenectomy, low IgA level, and later age of onset of CVID, while had been already associated with the reduction of IgG class-switched B-cells (CD27+IgM-IgD-) in peripheral blood [83, 84]. Although the pathogenesis of AC in CVID is not completely understood, various mechanisms have been proposed: the reduction of $\mathrm{T}$ regulatory (Treg) cells, whose relevance is supported by the finding of high rates of both granulomatous disease and autoimmunity in the subset of CVID patients with very low Treg cells [85, 86], and the persistent antigenic exposure to microbial antigens, which could trigger autoimmunity by molecular mimicry [87]. Recently, Romberg et al. found that patients with CVID and AC displayed irregularly shaped hyperplastic germinal centers with an increase in numbers of 
circulating TFH cells correlating with decreased regulatory T-cell frequencies and function [88].

ITP is the most common AC in CVID with a $7 \%$ to $14 \%$, prevalence while the proportion of CVID patients with AIHA and $\mathrm{AN}$ is $4-7 \%$ and $1 \%$, respectively [56]. ITP is also the most challenging $\mathrm{AC}$ to manage, often requiring immunosuppressive combination protocols and multiple treatments [89].

The standard treatment of CVID-associated AC consists in the use of glucocorticoids up to at $1 \mathrm{mg} / \mathrm{kg}$ prednisone-equivalent, associated, if a rapid response is required, to high-dose intravenous immunoglobulin (IVIG) (1-2 g/kg in 5 days). Rho (D) immunoglobulin is an option for non-splenectomized Rh-positive subjects who cannot receive glucocorticoid treatment [90]. Although the initial response rates are around the $85 \%$, relapses are very frequent, thus requiring prolonged use of high-dose glucocorticoids [91-93]. Over the past decades, splenectomy has been the traditional second line approach in non-responders or relapsing patients and, behalf the introduction of RTX, up to the $50 \%$ of CVID-ITP patients required splenectomy as secondline treatment [19]. The largest multicenter retrospective study on splenectomy was carried out by the ESID in 2013 and reported the outcome of splenectomy in 45 CVID patients over a 4 decade period [94]. Splenectomy proved to be an effective long-term treatment in
ADCC: Antibody - Dependent

Cell - mediated Cytotoxicity

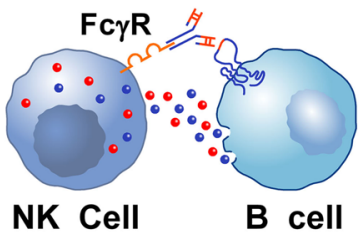

Complement - mediated Cytotoxicity

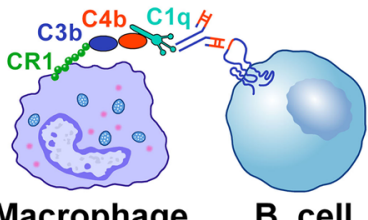

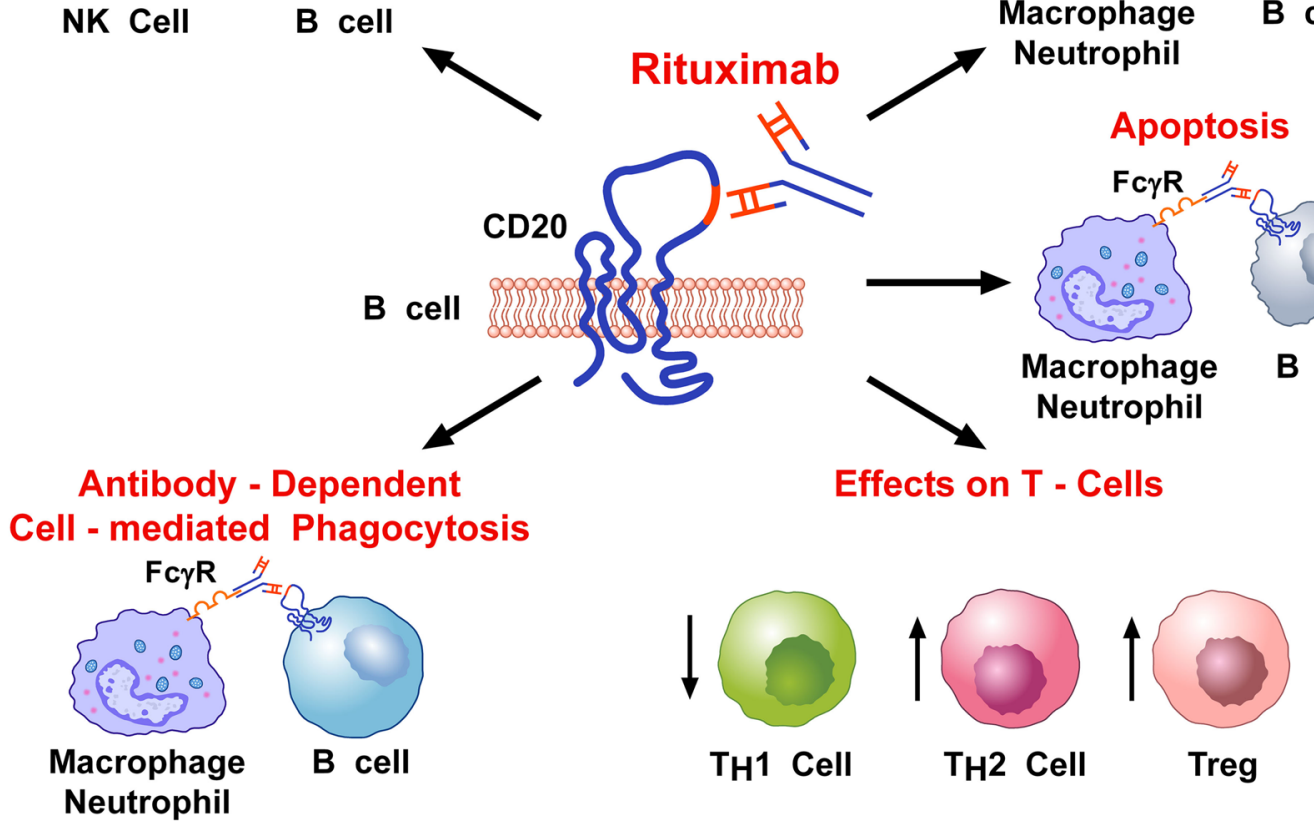

Fig. 1 Schematic representation of the multiple mechanisms that have been proposed to explain the immunosuppressive effects of RTX. RTX is a chimeric $\lg \mathrm{G}_{1}$ monoclonal antibody $(\mathrm{mAb})$ (the Fc domain is humanized, whereas the Fab domain is murine) that targets the CD20 protein on human B-cells. RTX depletes B-cells primarily through an antibody-dependent cell-mediated cytotoxicity (ADCC) and complement-mediated cytotoxicity (CMC). ADCC occurs through the engagement of Fcy receptor on NK cells by the Fc domain of RTX. Activated NK cells release perforin and granzymes that cause B-cell lysis. CMC occurs through the activation of the complement cascade by the interaction of RTX and CD20, the formation of anaphylatoxins (i.e., C5a, C3a) and the membrane attack complex. The Fcy receptor is also expressed by human macrophages and neutrophils. Therefore, RTX can also cause antibody-dependent phagocytosis of B-cells by macrophages and neutrophils. Moreover, RTX can cause the apoptosis of B cells through the induction of both CD20 cross-linking on surface membrane and MAP kinase activation. Indeed, apoptotic B-cells are cleared by phagocytes, such as macrophages and neutrophils, through Fcy receptor's activation. Finally, there is some evidence that RTX can decrease Th1 cells and can increase Th2 and Treg cells 
75\% of CVID patients with autoimmune cytopenia not worsening mortality.

RTX was first used for CVID-related AC, in 2004 [91]. After this report, various cases have described the outcomes of RTX in AC, reporting high response rates (up to $90 \%$ ) but also significant relapses (up to $78 \%$ ) [92, 93, 95-99]. In 2011, a multicenter retrospective study investigated the long-term outcome of RTX in 33 patients with CVID-associated refractory AC. RTX was usually given at standard dose, namely $375 \mathrm{mg} / \mathrm{m}^{2}$ once a week for 4 weeks. The authors found an overall initial response rate of $84 \%$ (with platelets $>30 \times 10^{3} / \mu \mathrm{l}$ or $\mathrm{Hb}>10 \mathrm{~g} /$ $\mathrm{dl}$ ), including $74 \%$ complete responses (defined as platelets $>100 \times 10^{3} / \mu \mathrm{l}$ or $\mathrm{Hb}>12 \mathrm{~g} / \mathrm{dl}$ ). Durable response rate (complete response lasting more than 12 months) was observed in 59\% patients. Major infections were the most frequent and severe adverse drug reaction $(24.2 \%, 8 / 33)$ over a mean follow-up period of 39 months [19]. However, the incidence of major infections was not different from that observed in CVID patients with AC undergoing the first line of treatment, including glucocorticoids with or without high-dose IVIG [91].

In conclusion, RTX may be considered an effective therapeutic option for CVID-related AC, in particular in the subset of patients who cannot receive long-term high-dose glucocorticoids or present surgical contraindications (i.e., portal system hemodynamic changes) to splenectomy. Moreover, the effectiveness of B-cell depletion suggests that other molecules targeting B-cells (i.e., bortezomib, epratuzumab, ibrutinib) may also be effective in CVID-related AC [100-102].

\section{Granulomatous lymphocytic interstitial lung disease}

A subset (5 to $22 \%$ ) of CVID patients develop granulomatous lymphocytic interstitial lung disease (GLILD) [103105]. The ethiopathogenetic features of this disorder are not completely understood and its characterization lies on both radiological abnormalities and histopathological findings [106]. Lymphocytic interstitial pneumonia (LIP), follicular bronchitis/bronchiolitis and granulomatous inflammation are the predominant histopathologic patterns, whereas the HR-CT finding of scattered nodules with areas of consolidation and ground glass, prominent on the lower zones, form the main radiographical pictures $[107,108]$.

Typical symptoms of GLILD are cough and dyspnea, while fever and pleuritic chest pain are rare. GLILD is frequently associated with splenomegaly, diffuse adenopathy, autoimmune cytopenias, and gastrointestinal and hepatic disease, thus suggesting a multi-systemic nature of the underlying pathogenesis. Various pathogenetic hypothesis have been proposed. Pulmonary granulomatous inflammation may develop in response to chronic antigenic stimulation, with pulmonary microenvironment preferentially favoring $\mathrm{T}$-cell proliferation with a subsequent B-cell recruitment. On the other hand, the intrinsic immune dysregulation typical of CVID may favor the development of interstitial lung disease, as observed in CVID-like monogenic diseases such as cytotoxic $\mathrm{T}$ lymphocyte associated protein-4 (CTLA-4) deficiency and signal transducer and activator of transcription 3 (STAT3) gain-of-function mutations. Finally, a relatively high frequency of EBV, HIV and HHV-8 has been found in lung samples from patients with LIP, suggesting that viruses may play a role in triggering the lymphocyte infiltrate associated with GLILD [103-108]. To date, there is no established standard of care for the treatment of patients with CVID and GLILD, nor when it is necessary to start the treatment. These are important issues, since GLILD has been associated to a poor prognostic outcome. An early intervention targeting the polyclonal lymphocytic infiltration may reduce the rates of disability and mortality. Empirical treatments, including glucocorticoids, cyclosporine and infliximab, have been used with variable results. In the last 6 years, various case reports and small cohort studies have described the outcome of RTX, alone or in combination with classical immunosuppressants, in CVID patients with GLILD [62, 109-113].

The largest series included seven patients, who were treated with RTX at the weekly dose of $375 \mathrm{mg} / \mathrm{m}^{2}$ for 4 weeks (repeated at 4-6 month intervals, for 3 or 4 total courses) and oral azathioprine $(1.0-2.0 \mathrm{mg} / \mathrm{kg} /$ day, 18 months duration) [62]. Post-treatment improvement was noted in both lung function (FEV1 and FVC) and radiographic findings (pulmonary consolidations, ground-glass, nodular opacities and bronchial wall thickening). No significant chemotherapy-related complications occurred. Similar results in terms of both effectiveness and safety were achieved in 4 case reports described between 2015 and 2017, by using the same therapeutic protocol including RTX and azathioprine [109-112]. In 2017 Jolles et al. described the use of 2-[(18)F]-fluoro-2-deoxy-D-glucose positron emission tomography and computed tomography (FDG PETCT) scanning for the monitoring of response in a CVID patient with GLILD, treated with 2 infusions of RTX at dose of $1 \mathrm{~g}$ (with an interval of $1 \mathrm{month}$ ) in combination with long-term standard-dose (1-2 g/day) mycophenolate [113]. An almost complete resolution of the previously identified high metabolic activity and a normalization in lymph node size and lung architecture were observed. Recently, a RTX monotherapy was evaluated in 3 CVID naive patients: RTX was followed by an improvement in the severity and extent of both interstitial lung lesions and mediastinal adenopathy in all patients [20]. 
Collectively, these data confirm the effectiveness and safety of RTX in CVID-associated GLILD. On the other hand, a recent Consensus Statement on the management of GLILD in CVID, carried out by the British Lung Foundation/United Kingdom Primary Immunodeficiency Network, reports a $91 \%$ consensus on the use of glucocorticoids alone as first-line treatment [63]. Definitively, there is still a lack of longitudinal data on the long-term outcome and the impact on overall survival of the various therapeutic agents.

\section{Non-malignant lymphoproliferation and other conditions}

A number of small series and case reports provide information about the effectiveness of RTX in various immune-mediated manifestations that are thought to be the result of the complex immune dysregulation of CVID. Salzer et al. described the successful outcome of RTX (375 mg/m² administered weekly 4 times) to treat the systemic inflammatory response and lymphoproliferative disorder associated with EBV persistent replication in a pediatric patient with monogenic-CVID due to an autosomal recessive CD27 deficiency [114]. A comparable outcome was obtained, with the same RTX dose in combination with glucocorticoids, for an EBV-related lymphoproliferation in a patient with a monogenic form of CVID due to a frameshift mutation in the NFKB1 gene leading to NF- $\mathrm{kB1}$ haploinsufficiency [115]. Similarly, RTX efficacy was reported in an adult patients with multiple monoclonal lymphoproliferative lesions [116].

Also granulomatous manifestations other than GLILD have been treated with RTX. A retrospective analysis of 59 CVID patients with granulomatous manifestations from the French DEFI cohort, found that standard dose RTX in combination with glucocorticoids, used in three patients, led to one complete and two partial responses of granulomatous lymph nodes and liver infiltrates [117].

Finally, the successful use of RTX have been reported in single cases of ANCA-associated vasculitis, Takayasu arteritis, renal granuloma, intra-cranial granulomata, bronchus-associated lymphoid tissue hyperplasia and cerebellar inflammatory lesions in patients with CVID [118-123].

\section{Conclusion}

There is compelling evidence that autoimmune and lymphoproliferative disorders strongly affect the long-term outcome of CVID patients. The management of these complications often require multiple lines of treatment including various immunosuppressive drugs. Although glucocorticoids remain the first line of treatment for all the complications of CVID associated with the immunedysregulation, over the last 5-10 years, RTX has proven to be an effective and relatively safe second-line therapy for both autoimmune and non-malignant lymphoproliferative manifestations. To date, there are no data on the long-term efficacy and side effects of RTX and other second-line therapeutic options. Further trials evaluating the head-to-head comparison between RTX and other second-line therapeutic options are needed to optimize the management strategies of non-infectious complications of CVID.

\begin{abstract}
Abbreviations
AC: autoimmune cytopenias; ADCC: antibody-dependent cell-mediated cytotoxicity; ADCP: antibody-dependent cell-mediated phagocytosis; AIHA: autoimmune hemolytic anemia; AN: autoimmune neutropenia; CVID: Common variable immunodeficiency; EMA: European Medicines Agency; FDA: Food and Drug Administration; GLILD: granulomatous lymphocytic interstitial lung disease; IgRT: immunoglobulin replacement therapy; ITP: immune thrombocytopenia; IVIG: intravenous immunoglobulin; RTX: rituximab.
\end{abstract}

\section{Authors' contributions}

All authors contributing equally to reviewing the current literature and writing of the manuscript. All authors read and approved the final manuscript.

\section{Author details}

${ }^{1}$ Department of Translational Medical Sciences and Center for Basic and Clinical Immunology Research (CISI), World Allergy Organization (WAO) Center of Excellence, University of Naples Federico II, Via S. Pansini 5, 80131 Naples, Italy. ${ }^{2}$ Department of Public Health, University of Naples Federico II, Naples, Italy. ${ }^{3}$ Monaldi Hospital Pharmacy, Naples, Italy. ${ }^{4}$ Centre for Experimental Medicine and Rheumatology, William Harvey Research Institute, Barts and The London School of Medicine and Dentistry, Queen Mary University of London, London, UK.

\section{Acknowledgements}

The authors apologize to the authors who have contributed importantly to this field and whose work has not been cited. The authors thank Fabrizio Fiorbianco for the elaboration of the figure.

\section{Competing interests}

The authors declare that they have no competing interests.

Availability of data and materials

Literature data used for this review are listed in the References section.

\section{Consent for publication}

All the authors consent to the publication of the manuscript and, in case of its acceptance, the copyright is transferred to Clinical and Molecular Allergy.

Ethics approval and consent to participate

Not applicable.

Funding

This study did not need any precise supply from funding organizations in the public, industrial or no longer-for-income sectors.

\section{Publisher's Note}

Springer Nature remains neutral with regard to jurisdictional claims in published maps and institutional affiliations.

Received: 8 March 2019 Accepted: 11 April 2019

Published online: 06 May 2019

\section{References}

1. Feugier P. A review of rituximab, the first anti-CD20 monoclonal antibody used in the treatment of B non-Hodgkin's lymphomas. Future Oncol. 2015;11(9):1327-42. https://doi.org/10.2217/fon.15.5. 
2. Du J, Wang H, Zhong C, Peng B, Zhang M, Li B, Huo S, Guo Y, Ding J. Structural basis for recognition of $C D 20$ by therapeutic antibody rituximab. J Biol Chem. 2007;282(20):15073-80.

3. Musette P, Bouaziz JD. B cell modulation strategies in autoimmune diseases: new concepts. Front Immunol. 2018;9:622. https://doi. org/10.3389/fimmu.2018.00622.

4. Oldham RJ, Cleary KLS, Cragg MS. CD20 and its antibodies: past, present, and future. Forum Immunopathol Dis Ther. 2014;5(1-2):7-23. https://doi.org/10.1615/ForumlmmunDisTher.2015014073.

5. Marshall MJE, Stopforth RJ, Cragg MS. Therapeutic antibodies: what have we learnt from targeting CD20 and where are we going? Front Immunol. 2017;8:1245. https://doi.org/10.3389/fimmu.2017.01245.

6. Pierpont TM, Limper CB, Richards KL. Past, present, and future of rituximab-the world's first oncology monoclonal antibody therapy. Front Oncol. 2018:8:163. https://doi.org/10.3389/fonc.2018.00163.

7. Kaplan B, Kopyltsova Y, Khokhar A, Lam F, Bonagura V. Rituximab and immune deficiency: case series and review of the literature. J Allergy Clin Immunol Pract. 2014;2(5):594-600.

8. Compagno N, Malipiero G, Cinetto F, Agostini C. Immunoglobulin replacement therapy in secondary hypogammaglobulinemia. Front Immunol. 2014;5:626. https://doi.org/10.3389/fimmu.2014.00626.

9. Spadaro G, Pecoraro A, De Renzo A, Della Pepa R, Genovese A. Intravenous versus subcutaneous immunoglobulin replacement in secondary hypogammaglobulinemia. Clin Immunol. 2016;166-167:103-4. https:// doi.org/10.1016/j.clim.2016.04.001.

10. Compagno N, Cinetto F, Semenzato G, Agostini C. Subcutaneous immunoglobulin in lymphoproliferative disorders and rituximab-related secondary hypogammaglobulinemia: a single-center experience in 61 patients. Haematologica. 2014;99(6):1101-6. https://doi.org/10.3324/ haematol.2013.101261.

11. Grillo-López AJ. Rituximab: an insider's historical perspective. Semin Oncol. 2000;27(6 Suppl 12):9-16.

12. Cinetto F, Compagno N, Scarpa R, Malipiero G, Agostini C. Rituximab in refractory sarcoidosis: a single centre experience. Clin Mol Allergy. 2015:13(1):19. https://doi.org/10.1186/s12948-015-0025-9.

13. Ghanima W, Khelif A, Waage A, Michel M, Tjønnfjord GE, Romdhan NB, Kahrs J, Darne B, Holme PA, RITP study group. Rituximab as secondline treatment for adult immune thrombocytopenia (the RITP trial): a multicentre, randomised, double-blind, placebo-controlled trial. Lancet. 2015;385(9978):1653-61.

14. Stasi R, Del Poeta G, Stipa E, Evangelista ML, Trawinska MM, Cooper N, Amadori S. Response to B-cell depleting therapy with rituximab reverts the abnormalities of T-cell subsets in patients with idiopathic thrombocytopenic purpura. Blood. 2007;110(8):2924-30.

15. Ryden-Aulin M, Boumpas D, Bultink I, Callejas Rubio JL, CaminalMontero $L$, Castro $A$, et al. Off-label use of rituximab for systemic lupus erythematosus in Europe. Lupus Sci Med. 2016;3(1):e000163. https://doi. org/10.1136/lupus-2016-000163.

16. Wang H, Zhang TT, Qi JQ, Chu TT, Miao M, Qiu HY, Fu CC, Tang XW, Ruan CG, Wu DP, Han Y. Incidence, risk factors, and clinical significance of Epstein-Barr virus reactivation in myelodysplastic syndrome after allogeneic haematopoietic stem cell transplantation. Ann Hematol. 2019. https://doi.org/10.1007/s00277-019-03603-3 (Epub ahead of print)

17. Raberahona M, Wackenheim C, Germi R, Carré M, Bulabois CE, Thiébaut A, Lupo J, Semenova T, Cahn JY, Morand P, Epaulard O. Dynamics of Epstein-Barr viral load after hematopoietic stem cell transplantation and effect of preemptive rituximab therapy. Transpl Infect Dis. 2016;18(6):889-95. https://doi.org/10.1111/tid.12618.

18. Walter JE, Farmer JR, Foldvari Z, Torgerson TR, Cooper MA. Mechanismbased strategies for the management of autoimmunity and immune dysregulation in primary immunodeficiencies. J Allergy Clin Immunol Pract. 2016;4(6):1089-100. https://doi.org/10.1016/j.jaip.2016.08.004.

19. Gobert D, Bussel JB, Cunningham-Rundles C, Galicier L, Dechartres A, Berezne A, Bonnotte B, DeRevel T, Auzary C, Jaussaud R, Larroche C, LeQuellec A, Ruivard M, Seve P, Smail A, Viallard JF, Godeau B, Hermine $\mathrm{O}$, Michel M. Efficacy and safety of rituximab in common variable immunodeficiency-associated immune cytopenias: a retrospective multicentre study on 33 patients. Br J Haematol. 2011;155(4):498-508. https://doi.org/10.1111/j.1365-2141.2011.08880.x.

20. Cereser L, De Carli R, Girometti R, De Pellegrin A, Reccardini F, Frossi $B$, De Carli M. Efficacy of rituximab as a single-agent therapy for the treatment of granulomatous and lymphocytic interstitial lung disease in patients with common variable immunodeficiency. J Allergy Clin Immunol Pract. 2019;7(3):1055-1057.e2. https://doi.org/10.1016/j. jaip.2018.10.041 (Epub 2018 Nov 5)

21. Bonilla FA, Barlan I, Chapel H, Costa-Carvalho BT, Cunningham-Rundles C, de la Morena MT, Espinosa-Rosales FJ, Hammarström L, Nonoyama S, Quinti I, Routes JM, Tang ML, Warnatz K. International consensus document (ICON): common variable immunodeficiency disorders. J Allergy Clin Immunol Pract. 2016;4(1):38-59. https://doi.org/10.1016/j. jaip.2015.07.025.

22. Jolles $\mathrm{S}$. The variable in common variable immunodeficiency: a disease of complex phenotypes. J Allergy Clin Immunol Pract. 2013;1 (6):545-56. https://doi.org/10.1016/j.jaip.2013.09.015 (quiz 557).

23. Azizi G, Hafezi N, Mohammadi H, Yazdani R, Alinia T, Tavakol M, Aghamohammadi A, Mirshafiey A. Abnormality of regulatory T cells in common variable immunodeficiency. Cell Immunol. 2017:315:11-7. https://doi. org/10.1016/j.cellimm.2016.12.007.

24. Ferrari S, Zuntini $R$, Lougaris $V$, Soresina $A$, Sourková $V$, Fiorini M, Martino S, Rossi P, Pietrogrande MC, Martire B, Spadaro G, Cardinale F, Cossu F, Pierani P, Quinti I, Rossi C, Plebani A. Molecular analysis of the pre-BCR complex in a large cohort of patients affected by autosomal-recessive agammaglobulinemia. Genes Immun. 2007;8(4):325-33.

25. Ebbo M, Gérard L, Carpentier S, Vély F, Cypowyj S, Farnarier C, Vince N, Malphettes M, Fieschi C, Oksenhendler E, Schleinitz N, Vivier E, DEFI Study Group. Low circulating natural killer cell counts are associated with severe disease in patients with common variable immunodeficiency. EBioMedicine. 2016;6:222-30. https://doi.org/10.1016/j.ebiom .2016.02.025.

26. Hel Z, Huijbregts RP, Xu J, Nechvatalova J, Vlkova M, Litzman J. Altered serum cytokine signature in common variable immunodeficiency. J Clin Immunol. 2014;34(8):971-8. https://doi.org/10.1007/s1087 5-014-0099-z.

27. Barbosa RR, Silva SP, Silva SL, Tendeiro R, Melo AC, Pedro E, Barbosa MP, Santos MC, Victorino RM, Sousa AE. Monocyte activation is a feature of common variable immunodeficiency irrespective of plasma lipopolysaccharide levels. Clin Exp Immunol. 2012;169(3):263-72. https://doi.org /10.1111/j.1365-2249.2012.04620.x.

28. Unger S, Seidl M, van Schouwenburg P, Rakhmanov M, Bulashevska A, Frede N, Grimbacher B, Pfeiffer J, Schrenk K, Munoz L, Hanitsch L, Stumpf I, Kaiser F, Hausmann O, Kollert F, Goldacker S, van der Burg M, Keller B, Warnatz K. The $T(H) 1$ phenotype of follicular helper T cells indicates an IFN- $\gamma$-associated immune dysregulation in patients with CD21 low common variable immunodeficiency. J Allergy Clin Immunol. 2018;141(2):730-40. https://doi.org/10.1016/j.jaci.2017.04.041.

29. Turpin D, Furudoi A, Parrens M, Blanco P, Viallard JF, Duluc D. Increase of follicular helper T cells skewed toward a Th1 profile in CVID patients with non-infectious clinical complications. Clin Immunol. 2018;197:130-8. https://doi.org/10.1016/j.clim.2018.09.006.

30. Pecoraro A, Nigro E, Polito R, Monaco ML, Scudiero O, Mormile I, Cesoni Marcelli A, Capasso M, Habetswallner F, Genovese A, Daniele A, Spadaro G. Total and high molecular weight adiponectin expression is decreased in patients with common variable immunodeficiency: correlation with Ig replacement therapy. Front Immunol. 2017:8:895. https ://doi.org/10.3389/fimmu.2017.00895.

31. Vlkova M, Chovancova Z, Nechvatalova J, Connelly AN, Davis MD, Slanina P, Travnickova L, Litzman M, Grymova T, Soucek P, Freiberger T, Litzman J, Hel Z. Neutrophil and granulocytic myeloid-derived suppressor cell-mediated T cell suppression significantly contributes to immune dysregulation in common variable immunodeficiency disorders. J Immunol. 2019;202(1):93-104. https://doi.org/10.4049/jimmu nol.1800102.

32. Pulvirenti F, Zuntini R, Milito C, Specchia F, Spadaro G, Danieli MG, Pession A, Quinti I, Ferrari S. Clinical associations of biallelic and monoallelic TNFRSF13B variants in Italian primary antibody deficiency syndromes. J Immunol Res. 2016;2016:8390356. https://doi.org/10.1155/2016/83903 56.

33. Borriello F, Longo M, Spinelli R, Pecoraro A, Granata F, Staiano RI, Loffredo S, Spadaro G, Beguinot F, Schroeder J, Marone G. IL-3 synergises with basophil-derived IL-4 and IL-13 to promote the alternative activation of human monocytes. Eur J Immunol. 2015;45(7):2042-51. https:// doi.org/10.1002/eji.201445303. 
34. Spadaro G, D'Orio C, Genovese A, Galeotafiore A, D'Ambrosio C, Di Giovanni S, Vitale M, Capasso M, Lamberti V, Scaloni A, Marone G, Zambrano N. Proteomic analysis of sera from common variable immunodeficiency patients undergoing replacement intravenous immunoglobulin therapy. J Biomed Biotechnol. 2011;2011:706746. https://doi. org/10.1155/2011/706746.

35. Vitiello L, Masci AM, Montella L, Perna F, Angelini DF, Borsellino G, Battistini L, Merola G, De Palma R, Spadaro G, Cosentini E, Palmieri G, Racioppi L. Thymoma-associated immunodeficiency: a syndrome characterized by severe alterations in NK, T and B-cells and progressive increase in naïve CD8+ T Cells. Int J Immunopathol Pharmacol. 2010;23(1):307-16.

36. Quinti I, Soresina A, Spadaro G, Martino S, Donnanno S, Agostini C, Claudio P, Franco D, Maria Pesce A, Borghese F, Guerra A, Rondelli R, Plebani A, Italian Primary Immunodeficiency Network. Long-term follow-up and outcome of a large cohort of patients with common variable immunodeficiency. J Clin Immunol. 2007;27(3):308-16.

37. Pecoraro A, Nappi L, Crescenzi L, D’Armiento FP, Genovese A, Spadaro G. Chronic diarrhea in common variable immunodeficiency: a case series and review of the literature. J Clin Immunol. 2018;38(1):67-76. https:// doi.org/10.1007/s10875-017-0461-z.

38. Varricchi G, Pecoraro A, Crescenzi L, Marone G, Travaglino A, D'Armiento FP, Genovese A, Spadaro G. Gastroduodenal disorders in patients with CVID undergoing immunoglobulin therapy. Curr Pharm Biotechnol. 2018;19(9):734-41. https://doi.org/10.2174/13892010196661810101 70630.

39. Megna M, Pecoraro A, Balato N, Villani A, Crescenzi L, Balato A, Spadaro $G$. Psoriasis in a cohort of patients with common variable immunodeficiency. Br J Dermatol. 2018. https://doi.org/10.1111/bjd.17408 (Epub ahead of print)

40. Schutz K, Alecsandru D, Grimbacher B, Haddock J, Bruining A, Driessen G, de Vries E, van Hagen PM, Hartmann I, Fraioli F, Milito C, Mitrevski M, Quinti I, Serra G, Kelleher P, Loebinger M, Litzman J, Postranecka V, Thon V, Babar J, Condliffe AM, Exley A, Kumararatne D, Screaton N, Jones A, Bondioni MP, Lougaris V, Plebani A, Soresina A, Sirignano C, Spadaro G, Galal N, Gonzalez-Granado LI, Dettmer S, Stirling R, Chapel H, Lucas M, Patel S, Farber CM, Meyts I, Banerjee AK, Hackett S, Hurst JR, Warnatz K, Gathmann B, Baumann U, Chest CT in Antibody Deficiency Group. Imaging of bronchial pathology in antibody deficiency: data from the European Chest CT Group. J Clin Immunol. 2019;39(1):45-54. https:// doi.org/10.1007/s10875-018-0577-9.

41. Dellepiane RM, Dell'Era L, Beilis LV, Pavesi P, Raimondi M, Soresina A, Lougaris V, Carrabba M, Martire B, Martino S, Russo G, Patuzzo G, Pignata C, Spadaro G, Gallizzi R, Duse M, Specchia FG, Moschese V, Marseglia GL, Pietrogrande MC, Bedogni G, Agostoni C. Nutritional status in agammaglobulinemia: an Italian multicenter study. J Clin Immunol. 2015;35(7):595-7. https://doi.org/10.1007/s10875-015-0195-8.

42. Graziano V, Pecoraro A, Mormile I, Quaremba G, Genovese A, Buccelli C, Paternoster M, Spadaro G. Delay in diagnosis affects the clinical outcome in a cohort of cvid patients with marked reduction of iga serum levels. Clin Immunol. 2017;180:1-4. https://doi.org/10.1016/j. clim.2017.03.011.

43. Pulvirenti F, Cinetto F, Pecoraro A, Carrabba M, Crescenzi L, Neri R, Bonanni L, Fabio G, Agostini C, Spadaro G, Tabolli S, Farrugia A, Quinti I, Milito C. Health-related quality of life in patients with CVID under different schedules of immunoglobulin administration: prospective multicenter study. J Clin Immunol. 2019. https://doi.org/10.1007/s1087 5-019-0592-5.

44. Soresina A, Nacinovich R, Bomba M, Cassani M, Molinaro A, Sciotto A, Martino S, Cardinale F, De Mattia D, Putti C, Dellepiane RM, Felici L, Parrinello G, Neri F, Plebani A, Italian Network for Primary Immunodeficiencies. The quality of life of children and adolescents with X-linked agammaglobulinemia. J Clin Immunol. 2009;29(4):501-7. https://doi. org/10.1007/s10875-008-9270-8.

45. Pecoraro A, Jolles S, Crescenzi L, Varricchi G, Marone G, Savoia M, Genovese A, Spadaro G. Validation of calculated globulin (CG) as a screening test for antibody deficiency in an Italian University Hospital. Curr Pharm Biotechnol. 2018;19(9):728-33. https://doi.org/10.2174/1389201019 666180808163311

46. Jolles S, Borrell R, Zouwail S, Heaps A, Sharp H, Moody M, Selwood C, Williams P, Phillips C, Hood K, Holding S, El Shanawany T. Calculated globulin (CG) as a screening test for antibody deficiency. Clin Exp Immunol. 2014;177(3):671-8. https://doi.org/10.1111/cei.12369.

47. Pecoraro A, Crescenzi L, Carucci L, Genovese A, Spadaro G. Heart failure not responsive to standard immunosuppressive therapy is successfully treated with high dose intravenous immunoglobulin therapy in a patient with Eosinophilic Granulomatosis with Polyangiitis (EGPA). Int Immunopharmacol. 2017;45:13-5. https://doi.org/10.1016/j.intim p.2017.01.025.

48. Quinti I, Soresina A, Guerra A, Rondelli R, Spadaro G, Agostini C, Milito C, Trombetta AC, Visentini M, Martini H, Plebani A, Fiorilli M, IPINet Investigators. Effectiveness of immunoglobulin replacement therapy on clinical outcome in patients with primary antibody deficiencies: results from a multicenter prospective cohort study. J Clin Immunol. 2011;31(3):315-22. https://doi.org/10.1007/s10875-011-9511-0.

49. Pecoraro A, Crescenzi L, Granata F, Genovese A, Spadaro G. Immunoglobulin replacement therapy in primary and secondary antibody deficiency: the correct clinical approach. Int Immunopharmacol. 2017:52:136-42. https://doi.org/10.1016/j.intimp.2017.09.005.

50. Spadaro G, Vultaggio A, Alberto Bosi A, Reichert D, Janssen J, Lamacchia D, Nappi L, Pecoraro A, Milito C, Ferraro A, Matucci A, Bacchiarri F, Carrai V, Hibbeler A, Speckman E, Guarnieri C, Bongiovanni S, Quinti I. Rapid infusions of human normal immunoglobulin $50 \mathrm{~g} / \mathrm{l}$ are safe and well tolerated in immunodeficiencies and immune thrombocytopenia. Int Immunopharmacol. 2017;44:38-42. https://doi.org/10.1016/j.intim p.2016.12.030.

51. Vultaggio A, Azzari C, Milito C, Finocchi A, Toppino C, Spadaro G, Trizzino A, Baldassarre M, Paganelli R, Moschese V, Soresina A, Matucci A. Subcutaneous immunoglobulin replacement therapy in patients with primary immunodeficiency in routine clinical practice: the VISPO prospective multicenter study. Clin Drug Investig. 2015;35(3):179-85. https://doi.org/10.1007/s40261-015-0270-1.

52. Canessa C, lacopelli J, Pecoraro A, Spadaro G, Matucci A, Milito C, Vultaggio A, Agostini C, Cinetto F, Danieli MG, Gambini S, Marasco C, Trizzino A, Vacca A, De Mattia D, Martire B, Plebani A, Di Gioacchino M, Gatta A, Finocchi A, Licciardi F, Martino S, De Carli M, Moschese V, Azzari C. Shift from intravenous or $16 \%$ subcutaneous replacement therapy to $20 \%$ subcutaneous immunoglobulin in patients with primary antibody deficiencies. Int J Immunopathol Pharmacol. 2017;30(1):73-82. https:// doi.org/10.1177/0394632016681577.

53. Vultaggio A, Azzari C, Ricci S, Martire B, Palladino V, Gallo V, Pecoraro A, Pignata C, Spadaro G, Graziani S, Moschese V, Trizzino A, Boggia GM, Matucci A. Biweekly Hizentra ${ }^{\circledR}$ in primary immunodeficiency: a multicenter, observational cohort study (IBIS). J Clin Immunol. 2018;38(5):602-9. https://doi.org/10.1007/s10875-018-0528-5.

54. Viti R, Marcellusi A, Capone A, Matucci A, Vultaggio A, Pignata C, Spadaro G, Vacca A, Marasco C, Agostini C, Mennini FS. Direct and indirect costs of immunoglobulin replacement therapy in patients with common variable immunodeficiency (CVID) and X-linked agammaglobulinemia (XLA) in Italy. Clin Drug Investig. 2018;38(10):955-65. https:// doi.org/10.1007/s40261-018-0688-3.

55. Quinti I, Soresina A, Agostini C, Spadaro G, Matucci A, Sfika I, Martini H, Borghese F, Guerra A, Alessandra V, Visentini M, Plebani A, Fiorilli M. Prospective study on CVID patients with adverse reactions to intravenous or subcutaneous IgG administration. J Clin Immunol. 2008;28(3):263-7. https://doi.org/10.1007/s10875-007-9169-9.

56. Resnick ES, Moshier EL, Godbold JH, Cunningham-Rundles C. Morbidity and mortality in common variable immune deficiency over 4 decades. Blood. 2012;119(7):1650-7. https://doi.org/10.1182/blood-2011-09377945.

57. Quinti I, Agostini C, Tabolli S, Brunetti G, Cinetto F, Pecoraro A, Spadaro G. Malignancies are the major cause of death in patients with adult onset common variable immunodeficiency. Blood. 2012;120(9):1953-4. https://doi.org/10.1182/blood-2012-05-431064.

58. Pulvirenti F, Pecoraro A, Cinetto F, Milito C, Valente M, Santangeli E, Crescenzi L, Rizzo F, Tabolli S, Spadaro G, Agostini C, Quinti I. Gastric cancer is the leading cause of death in Italian adult patients with common variable immunodeficiency. Front Immunol. 2018;9:2546. https://doi. org/10.3389/fimmu.2018.02546.

59. Cunningham-Rundles $C$. Autoimmune manifestations in common variable immunodeficiency. J Clin Immunol. 2008;28(Suppl 1):S42-5. https ://doi.org/10.1007/s10875-008-9182-7. 
60. Chua I, Standish R, Lear S, Harbord M, Eren E, Raeiszadeh M, Workman S, Webster D. Anti-tumour necrosis factor-alpha therapy for severe enteropathy in patients with common variable immunodeficiency (CVID). Clin Exp Immunol. 2007;150(2):306-11.

61. Sanges M, Spadaro G, Miniero M, Mattera D, Sollazzo R, D'Armiento FP, De Palma GD, Pecoraro A, Borrelli F, Genovese A, D'Arienzo A. Efficacy of subcutaneous immunoglobulins in primary immunodeficiency with Crohn's-like phenotype: report of a case. Eur Rev Med Pharmacol Sci. 2015;19(14):2641-5.

62. Chase NM, Verbsky JW, Hintermeyer MK, Waukau JK, Tomita-Mitchell A, Casper JT, Singh S, Shahir KS, Tisol WB, Nugent ML, Rao RN, Mackinnon AC, Goodman LR, Simpson PM, Routes JM. Use of combination chemotherapy for treatment of granulomatous and lymphocytic interstitial lung disease (GLILD) in patients with common variable immunodeficiency (CVID). J Clin Immunol. 2013;33(1):30-9. https://doi.org/10.1007/ s10875-012-9755-3.

63. Hurst JR, Verma N, Lowe D, Baxendale HE, Jolles S, Kelleher P, Longhurst HJ, Patel SY, Renzoni EA, Sander CR, Avery GR, Babar JL, Buckland MS, Burns S, Egner W, Gompels MM, Gordins P, Haddock JA, Hart SP, Hayman GR, Herriot R, Hoyles RK, Huissoon AP, Jacob J, Nicholson AG, Rassl DM, Sargur RB, Savic S, Seneviratne SL, Sheaff M, Vaitla PM, Walters GI, Whitehouse JL, Wright PA, Condliffe AM. British Lung Foundation/United Kingdom Primary Immunodeficiency Network consensus statement on the definition, diagnosis, and management of granulomatous-lymphocytic interstitial lung disease in common variable immunodeficiency disorders. J Allergy Clin Immunol Pract. 2017;5(4):938-45. https://doi. org/10.1016/j.jaip.2017.01.021.

64. Bethune C, Egner W, Garcez T, Huissoon A, Jolles S, Karim Y, Jain R, Savic S, Kelley K, Grosse-Kreul D, Grigoriadou S. British Society for Immunology/United Kingdom Primary Immunodeficiency Network consensus statement on managing non-infectious complications of common variable immunodeficiency disorders. Clin Exp Immunol. 2019;56:78. https://doi.org/10.1111/cei.13272.

65. Weiner GJ. Rituximab: mechanism of action. Semin Hematol. 2010:47(2):115-23. https://doi.org/10.1053/j.seminhematol.2010.01.011.

66. Stevenson FK, Stevenson GT. Follicular lymphoma and the immune system: from pathogenesis to antibody therapy. Blood. 2012;119(16):365967. https://doi.org/10.1182/blood-2011-11-367730.

67. Degn SE, Thiel S. Humoral pattern recognition and the complement system. Scand J Immunol. 2013;78(2):181-93. https://doi.org/10.1111/ sji.12070.

68. Merle NS, Church SE, Fremeaux-Bacchi V, Roumenina LT. Complement system part I-molecular mechanisms of activation and regulation. Front Immunol. 2015;6:262. https://doi.org/10.3389/fimmu.2015.00262.

69. Golay J, Zaffaroni L, Vaccari T, Lazzari M, Borleri GM, Bernasconi $S$, Tedesco F, Rambaldi A, Introna M. Biologic response of B lymphoma cells to anti-CD20 monoclonal antibody rituximab in vitro: CD55 and CD59 regulate complement-mediated cell lysis. Blood. 2000;95(12):3900-8.

70. Musolino A, Naldi N, Bortesi B, Pezzuolo D, Capelletti M, Missale G, Laccabue D, Zerbini A, Camisa R, Bisagni G, Neri TM, Ardizzoni A. Immunoglobulin $\mathrm{G}$ fragment $\mathrm{C}$ receptor polymorphisms and clinical efficacy of trastuzumab-based therapy in patients with HER-2/neu-positive metastatic breast cancer. J Clin Oncol. 2008;26(11):1789-96. https://doi. org/10.1200/JCO.2007.14.8957.

71. Wang SY, Racila E, Taylor RP, Weiner GJ. NK-cell activation and antibodydependent cellular cytotoxicity induced by rituximab-coated target cells is inhibited by the C3b component of complement. Blood. 2008;111(3):1456-63.

72. Wang SY, Veeramani S, Racila E, Cagley J, Fritzinger DC, Vogel CW, St John W, Weiner GJ. Depletion of the C3 component of complement enhances the ability of rituximab-coated target cells to activate human NK cells and improves the efficacy of monoclonal antibody therapy in an in vivo model. Blood. 2009;114(26):5322-30. https://doi.org/10.1182/ blood-2009-01-200469.

73. Rudnicka D, Oszmiana A, Finch DK, Strickland I, Schofield DJ, Lowe DC, Sleeman MA, Davis DM. Rituximab causes a polarization of B cells that augments its therapeutic function in NK-cell-mediated antibodydependent cellular cytotoxicity. Blood. 2013;121(23):4694-702. https:// doi.org/10.1182/blood-2013-02-482570.
74. Flannagan RS, Jaumouillé V, Grinstein $\mathrm{S}$. The cell biology of phagocytosis. Annu Rev Pathol. 2012;7:61-98. https://doi.org/10.1146/annur ev-pathol-011811-132445.

75. Leandro MJ. B-cell subpopulations in humans and their differential susceptibility to depletion with anti-CD20 monoclonal antibodies. Arthritis Res Ther. 2013;15(Suppl 1):S3. https://doi.org/10.1186/ar3908.

76. Audia S, Samson M, Guy J, Janikashvili N, Fraszczak J, Trad M, Ciudad M, Leguy V, Berthier S, Petrella T, Aho-Glélé S, Martin L, Maynadié M, Lorcerie B, Rat P, Cheynel N, Katsanis E, Larmonier N, Bonnotte B. Immunologic effects of rituximab on the human spleen in immune thrombocytopenia. Blood. 2011;118(16):4394-400. https://doi.org/10.1182/ blood-2011-03-344051.

77. Rezvani AR, Maloney DG. Rituximab resistance. Best Pract Res Clin Haematol. 2011;24(2):203-16. https://doi.org/10.1016/j.beha.2011.02.009.

78. Beers SA, French RR, Chan HT, Lim SH, Jarrett TC, Vidal RM, Wijayaweera SS, Dixon SV, Kim H, Cox KL, Kerr JP, Johnston DA, Johnson PW, Verbeek JS, Glennie MJ, Cragg MS. Antigenic modulation limits the efficacy of anti-CD20 antibodies: implications for antibody selection. Blood. 2010;115(25):5191-201. https://doi.org/10.1182/blood-2010-01-263533.

79. Looney RJ, Anolik JH, Campbell D, Felgar RE, Young F, Arend LJ, Sloand JA, Rosenblatt J, Sanz I. B cell depletion as a novel treatment for systemic lupus erythematosus: a phase I/II dose-escalation trial of rituximab. Arthritis Rheum. 2004;50(8):2580-9.

80. Albert D, Dunham J, Khan S, Stansberry J, Kolasinski S, Tsai D, PullmanMooar S, Barnack F, Striebich C, Looney RJ, Prak ET, Kimberly R, Zhang $Y$, Eisenberg R. Variability in the biological response to anti-CD20 B cell depletion in systemic lupus erythaematosus. Ann Rheum Dis. 2008;67(12):1724-31. https://doi.org/10.1136/ard.2007.083162.

81. van de Ven AA, Warnatz $K$. The autoimmune conundrum in common variable immunodeficiency disorders. Curr Opin Allergy Clin Immunol. 2015;15(6):514-24. https://doi.org/10.1097/ACl.0000000000000218.

82. Chapel H, Lucas M, Patel S, Lee M, Cunningham-Rundles C, Resnick E, Gerard L, Oksenhendler E. Confirmation and improvement of criteria for clinical phenotyping in common variable immunodeficiency disorders in replicate cohorts. J Allergy Clin Immunol. 2012;130(5):1197-1198.e9. https://doi.org/10.1016/j.jaci.2012.05.046.

83. Gathmann B, Mahlaoui N, CEREDIH, Gérard L, Oksenhendler E, Warnatz K, Schulze I, Kindle G, Kuijpers TW, Dutch WID, van Beem RT, Guzman D, Workman S, Soler-Palacín P, De Gracia J, Witte T, Schmidt RE, Litzman J, Hlavackova E, Thon V, Borte M, Borte S, Kumararatne D, Feighery C, Longhurst H, Helbert M, Szaflarska A, Sediva A, Belohradsky BH, Jones A, Baumann U, Meyts I, Kutukculer N, Wågström P, Galal NM, Roesler J, Farmaki E, Zinovieva N, Ciznar P, Papadopoulou-Alataki E, Bienemann K, Velbri S, Panahloo Z, Grimbacher B, European Society for Immunodeficiencies Registry Working Party. Clinical picture and treatment of 2212 patients with common variable immunodeficiency. J Allergy Clin Immunol. 2014;134(1):116-26. https://doi.org/10.1016/j. jaci.2013.12.1077.

84. Wehr C, Kivioja T, Schmitt C, Ferry B, Witte T, Eren E, Vlkova M, Hernan$\operatorname{dez}$ M, Detkova D, Bos PR, Poerksen G, von Bernuth H, Baumann U, Goldacker S, Gutenberger S, Schlesier M, Bergeron-van der Cruyssen F, Le Garff M, Debré P, Jacobs R, Jones J, Bateman E, Litzman J, van Hagen PM, Plebani A, Schmidt RE, Thon V, Quinti I, Espanol T, Webster AD, Chapel H, Vihinen M, Oksenhendler E, Peter HH, Warnatz K. The EUROclass trial: defining subgroups in common variable immunodeficiency. Blood. 2008;111(1):77-85.

85. Horn J, Manguiat A, Berglund LJ, Knerr V, Tahami F, Grimbacher B, Fulcher DA. Decrease in phenotypic regulatory $T$ cells in subsets of patients with common variable immunodeficiency. Clin Exp Immunol. 2009;156(3):446-54. https://doi.org/10.1111/j.1365-2249.2009.03913.x.

86. Azizi G, Abolhassani H, Kiaee F, Tavakolinia N, Rafiemanesh H, Yazdani R, Mahdaviani SA, Mohammadikhajehdehi S, Tavakol M, Ziaee V, Negahdari B, Mohammadi J, Mirshafiey A, Aghamohammadi A. Autoimmunity and its association with regulatory $T$ cells and B cell subsets in patients with common variable immunodeficiency. Allergol Immunopathol. 2018;46(2):127-35. https://doi.org/10.1016/j.aller.2017.04.004.

87. Brandt D, Gershwin ME. Common variable immune deficiency and autoimmunity. Autoimmun Rev. 2006;5:465-70.

88. Romberg N, Le Coz C, Glauzy S, Schickel JN, Trofa M, Nolan BE, Paessler M, Xu ML, Lambert MP, Lakhani SA, Khokha MK, Jyonouchi S, Heimall J, Takach P, Maglione PJ, Catanzaro J, Hsu Fl, Sullivan KE, 
Cunningham-Rundles C, Meffre E. Patients with common variable immunodeficiency with autoimmune cytopenias exhibit hyperplastic yet inefficient germinal center responses. J Allergy Clin Immunol. 2019;143(1):258-65. https://doi.org/10.1016/j.jaci.2018.06.012.

89. Podjasek JC, Abraham RS. Autoimmune cytopenias in common variable immunodeficiency. Front Immunol. 2012;3:189. https://doi. org/10.3389/fimmu.2012.00189.

90. Neunert CE, Cooper N. Evidence-based management of immune thrombocytopenia: ASH guideline update. Hematol Am Soc Hematol Educ Program. 2018;2018(1):568-75. https://doi.org/10.1182/ashed ucation-2018.1.568.

91. Michel M, Chanet V, Galicier L, Ruivard M, Levy Y, Hermine O, Oksenhendler E, Schaeffer A, Bierling P, Godeau B. Autoimmune thrombocytopenic purpura and common variable immunodeficiency: analysis of 21 cases and review of the literature. Medicine. 2004;83(4):254-63.

92. Sève P, Bourdillon L, Sarrot-Reynauld F, Ruivard M, Jaussaud R, Bouhour D, Bonotte B, Gardembas M, Poindron V, Thiercelin MF, Broussolle C, Oksenhendler E, DEF-I Study Group. Autoimmune hemolytic anemia and common variable immunodeficiency: a case-control study of 18 patients. Medicine. 2008:87(3):177-84. https://doi.org/10.1097/ md.0b013e31817a90ba

93. Wakim M, Shah A, Arndt PA, Garratty G, Weinberg K, Hofstra T, Church J. Successful anti-CD20 monoclonal antibody treatment of severe autoimmune hemolytic anemia due to warm reactive IgM autoantibody in a child with common variable immunodeficiency. Am J Hematol. 2004;76(2):152-5.

94. Wong GK, Goldacker S, Winterhalter C, Grimbacher B, Chapel H, Lucas M, Alecsandru D, McEwen D, Quinti I, Martini H, Milito C, Schmidt RE, Ernst D, Espanol T, Vidaller A, Carbone J, Fernandez-Cruz E, Lougaris V, Plebani A, Kutukculer N, Gonzalez-Granado LI, Contreras R, KianiAlikhan S, Ibrahim MA, Litzman J, Jones A, Gaspar HB, Hammarstrom L, Baumann U, Warnatz K, Huissoon AP, Clinical Working Party of the European Society for Immunodeficiencies (ESID). Outcomes of splenectomy in patients with common variable immunodeficiency (CVID): a survey of 45 patients. Clin Exp Immunol. 2013;172(1):63-72. https://doi. org/10.1111/cei.12039.

95. Carbone J, Escudero A, Mayayo M, Ballesteros M, Perez-Corral A, Sanchez-Ramon S, Sarmiento E, Micheloud D, Fernandez-Cruz E. Partial response to anti-CD20 monoclonal antibody treatment of severe immune thrombocytopenic purpura in a patient with common variable immunodeficiency. Ann N Y Acad Sci. 2005;1051:666-71.

96. Mahévas M, Le Page L, Salle V, Cevallos R, Smail A, Duhaut P, Ducroix JP. Efficiency of rituximab in the treatment of autoimmune thrombocytopenic purpura associated with common variable immunodeficiency. Am J Hematol. 2006;81 (8):645-6.

97. El-Shanawany TM, Williams PE, Jolles S. Response of refractory immune thrombocytopenic purpura in a patient with common variable immunodeficiency to treatment with rituximab. J Clin Pathol. 2007;60(6):715-6.

98. Kim JJ, Thrasher AJ, Jones AM, Davies EG, Cale CM. Rituximab for the treatment of autoimmune cytopenias in children with immune deficiency. Br J Haematol. 2007;138(1):94-6.

99. Ardeniz O, Cunningham-Rundles C. Granulomatous disease in common variable immunodeficiency. Clin Immunol. 2009;133(2):198-207. https ://doi.org/10.1016/j.clim.2009.05.001.

100. Alexander T, Sarfert R, Klotsche J, Kühl AA, Rubbert-Roth A, Lorenz HM, Rech J, Hoyer BF, Cheng Q, Waka A, Taddeo A, Wiesener M, Schett G, Burmester GR, Radbruch A, Hiepe F, Voll RE. The proteasome inhibitior bortezomib depletes plasma cells and ameliorates clinical manifestations of refractory systemic lupus erythematosus. Ann Rheum Dis. 2015;74(7):1474-8. https://doi.org/10.1136/annrheumdis-2014-206016.

101. Gottenberg JE, Dörner T, Bootsma H, Devauchelle-Pensec V, Bowman SJ, Mariette X, Bartz H, Oortgiesen M, Shock A, Koetse W, Galateanu C, Bongardt S, Wegener WA, Goldenberg DM, Meno-Tetang G, Kosutic G, Gordon C. Efficacy of epratuzumab, an anti-CD22 monoclonal lgG antibody, in systemic lupus erythematosus patients with associated Sjögren's syndrome: post hoc analyses from the EMBODY trials. Arthritis Rheumatol. 2018;70(5):763-73. https://doi.org/10.1002/art.40425.

102. Rogers KA, Ruppert AS, Bingman A, Andritsos LA, Awan FT, Blum KA, Flynn JM, Jaglowski SM, Lozanski G, Maddocks KJ, Byrd JC, Woyach JA, Jones JA. Incidence and description of autoimmune cytopenias during treatment with ibrutinib for chronic lymphocytic leukemia. Leukemia. 2016;30(2):346-50. https://doi.org/10.1038/leu.2015.273.

103. Park JH, Levinson Al. Granulomatous-lymphocytic interstitial lung disease (GLILD) in common variable immunodeficiency (CVID). Clin Immunol. 2010;134(2):97-103. https://doi.org/10.1016/j.clim.2009.10.002.

104. Prasse A, Kayser G, Warnatz K. Common variable immunodeficiencyassociated granulomatous and interstitial lung disease. Curr Opin Pulm Med. 2013;19(5):503-9. https://doi.org/10.1097/MCP.0b013e3283642c4 7.

105. Hartono S, Motosue MS, Khan S, Rodriguez V, Iyer VN, Divekar R, Joshi AY. Predictors of granulomatous lymphocytic interstitial lung disease in common variable immunodeficiency. Ann Allergy Asthma Immunol. 2017;1 18(5):614-20. https://doi.org/10.1016/j.anai.2017.01.004.

106. Rao N, Mackinnon AC, Routes JM. Granulomatous and lymphocytic interstitial lung disease: a spectrum of pulmonary histopathologic lesions in common variable immunodeficiency —histologic and immunohistochemical analyses of 16 cases. Hum Pathol. 2015;46(9):1306-14. https://doi.org/10.1016/j.humpath.2015.05.011.

107. Mannina A, Chung JH, Swigris JJ, Solomon JJ, Huie TJ, Yunt ZX, Truong TQ, Brown KK, Achcar RD, Olson AL, Cox CW, Kligerman SJ, CurranEverett D, Fernández Pérez ER. Clinical predictors of a diagnosis of common variable immunodeficiency-related granulomatous-lymphocytic interstitial lung disease. Ann Am Thorac Soc. 2016;13(7):1042-9. https:// doi.org/10.1513/AnnalsATS.201511-7280C.

108. Maglione PJ, Overbey JR, Cunningham-Rundles C. Progression of common variable immunodeficiency interstitial lung disease accompanies distinct pulmonary and laboratory findings. J Allergy Clin Immunol Pract. 2015;3(6):941-50. https://doi.org/10.1016/j.jaip.2015.07.004.

109. Vitale J, Convers KD, Goretzke S, Guzman M, Noyes B, Parkar N, Knutsen AP. Serum IL-12 and soluble IL-2 receptor levels as possible biomarkers of granulomatous and lymphocytic interstitial lung disease in common variable immunodeficiency: a case report. J Allergy Clin Immunol Pract. 2015;3(2):273-6. https://doi.org/10.1016/j.jaip.2014.09.019.

110. Pathria M, Urbine D, Zumberg MS, Guarderas J. Management of granulomatous lymphocytic interstitial lung disease in a patient with common variable immune deficiency. BMJ Case Rep. 2016. https://doi. org/10.1136/bcr-2016-215624.

111. Routes JM, Verbsky JW. Immunodeficiency presenting as an undiagnosed disease. Pediatr Clin N Am. 2017;64(1):27-37. https://doi. org/10.1016/j.pcl.2016.08.007.

112. Shah JL, Amin SB, Verma N, Mohammed TL. Granulomatous-lymphocytic interstitial lung disease in a patient with common variable immunodeficiency. Curr Probl Diagn Radiol. 2018;47(4):282-4. https:// doi.org/10.1067/j.cpradiol.2017.04.007.

113. Jolles S, Carne E, Brouns M, El-Shanawany T, Williams P, Marshall C, Fielding P. FDG PET-CT imaging of therapeutic response in granulomatous lymphocytic interstitial lung disease (GLILD) in common variable immunodeficiency (CVID). Clin Exp Immunol. 2017;187(1):138-45. https ://doi.org/10.1111/cei.12856.

114. Salzer E, Daschkey S, Choo S, Gombert M, Santos-Valente E, Ginzel S, Schwendinger M, Haas OA, Fritsch G, PickI WF, Förster-Waldl E, Borkhardt A, Boztug K, Bienemann K, Seidel MG. Combined immunodeficiency with life-threatening EBV-associated lymphoproliferative disorder in patients lacking functional CD27. Haematologica. 2013;98(3):473-8. https://doi.org/10.3324/haematol.2012.068791.

115. Boztug H, Hirschmugl T, Holter W, Lakatos K, Kager L, Trapin D, PickI W, Förster-Waldl E, Boztug K. NF-KB1 haploinsufficiency causing immunodeficiency and EBV-driven lymphoproliferation. J Clin Immunol. 2016;36(6):533-40. https://doi.org/10.1007/s10875-016-0306-1.

116. Boursiquot JN, Gérard L, Malphettes M, Fieschi C, Galicier L, Boutboul D, Borie R, Viallard JF, Soulas-Sprauel P, Berezne A, Jaccard A, Hachulla E, Haroche J, Schleinitz N, Têtu L, Oksenhendler E, DEFI study group. Granulomatous disease in CVID: retrospective analysis of clinical characteristics and treatment efficacy in a cohort of 59 patients. J Clin Immunol. 2013;33(1):84-95. https://doi.org/10.1007/s10875-012-9778-9.

117. Williams SA, Moench LE, Khan F, Vercellotti G, Linden MA. Clonal lymphoproliferations in a patient with common variable immunodeficiency. Lab Med. 2016;47(4):318-25.

118. Hill F, Yonkof J, Chaitanya Arudra SK, Thomas J, Altorok N. Successful treatment of ANCA-associated vasculitis in the setting of 
common variable immunodeficiency using rituximab. Am JTher. 2016;23(5):e1239-45. https://doi.org/10.1097/MJT.0000000000000323.

119. Benoit G, Lapeyraque AL, Sartelet H, Saint-Cyr C, Le Deist F, Haddad E. Renal granuloma and immunoglobulin M-complex glomerulonephritis: a case of common variable immunodeficiency? Pediatr Nephrol. 2009;24(3):601-4. https://doi.org/10.1007/s00467-008-0958-z.

120. Najem CE, Springer J, Prayson R, Culver DA, Fernandez J, Tavee J, Hajj-Ali RA. Intra cranial granulomatous disease in common variable immunodeficiency: case series and review of the literature. Semin Arthritis Rheum. 2018;47(6):890-6. https://doi.org/10.1016/j.semarthrit 2017.10.014.

121. Mock JR, Kolb TM, Illei PB, Yang SC, Lederman HM, Merlo CA. Bronchusassociated lymphoid tissue in kabuki syndrome with associated
hyper-IgM syndrome/common variable immunodeficiency. Am J Respir Crit Care Med. 2016;194(4):514-5. https://doi.org/10.1164/rccm.20151 1-2305IM.

122. Nguyen JT, Green A, Wilson MR, DeRisi IL, Gundling K. Neurologic complications of common variable immunodeficiency. J Clin Immunol. 2016;36(8):793-800.

123. Skeik N, Rumery KK, Udayakumar PD, Crandall BM, Warrington KJ, Sullivan TM. Concurrent Takayasu arteritis with common variable immunodeficiency and moyamoya disease. Ann Vasc Surg. 2013;27(2):240. e13-8. https://doi.org/10.1016/j.avsg.2012.09.003.
Ready to submit your research? Choose BMC and benefit from:

- fast, convenient online submission

- thorough peer review by experienced researchers in your field

- rapid publication on acceptance

- support for research data, including large and complex data types

- gold Open Access which fosters wider collaboration and increased citations

- maximum visibility for your research: over 100M website views per year

At BMC, research is always in progress.

Learn more biomedcentral.com/submissions 